\title{
Depression in Someone Who Has Divorce
}

\section{Andria Pragholapati}

Depression disorder is a type of mental illness that often occurs in the community. The prevalence of depressive disorders in Indonesia is as much as $11.60 \%$ of the total population in Indonesia around 24.708,000 people and 50 percent occur at the age of 20-50 years ( $\mathrm{MOH}$, 2011). In addition, according to the World Health Organization (WHO) 2011, Depression is a complex disorder that affects more than 120 million people worldwide (Lepine \& Briley, 2011) and is predicted to be the second largest cause of disability in the world by 2020. In 2012 the WHO estimated depression to strike 350 million people (WHO, 2012). A survey conducted by the World Mental Health Survey of 17 countries found that on average 1 in 20 people experience depression.

According to Stuart (2013), depression is the occurrence of sadness and loss that is universal in the long term (ongoing stress). In addition, depression is a common mental disorder that presents with depressed mood, loss of interest or pleasure, feelings of guilt or low self-esteem, disturbed sleep or appetite, low energy, and loss of concentration. This problem can become chronic or recurring and cause a major disruption in the ability of individuals to take care of their daily responsibilities (WHO, 2011). Depressive episodes usually last for 6 to 9 months, but in $15-20 \%$ sufferers can last for 2 years or more.

Based on some of the definitions above it can be concluded that depression is sadness or ongoing stress and causes disruption to the roles and responsibilities of individuals who experience it. Depression occurs due to several factors, including physical factors and problems of health function, economic status, and marital status. In addition, other factors that influence the level of education, employment status, sociodemographic factors, low social support and cognitive function, chronic illness, history of risk of self-injury, family history of psychiatric problems and history of drug use, as well as criminal experience and violence (Diefenbach, et al., 2009).

Depression most often occurs in people who do not have close interpersonal relationships or in those who are divorced or separated. Unmarried women have a lower tendency to suffer from depression than those who are married but this is inversely proportional for men. Patients with depressive disorders have high rates of divorce, and about 50 percent of couples reported not to get married or have children if they know they have a depressive disorder (Ismail and Siste, 2014).

Nursing Department, Faculty of Sport Education and Health Sciences

Universitas Pendidikan Indonesia

Email: andria.pragholapati@upi.edu

1) P a g e 


\section{REFERENCES}

Ade, M.S., Tjutju, Pragholapati, A., 2016. GAMBARAN KUALITAS HIDUP PADA LANSIA DI BALAI PERLINDUNGAN SOSIAL TRESNA WERDHA CIPARAY BANDUNG TAHUN 2016.

http://ejurnal.stikesbhaktikencana.ac.id/file.php?file=preview_mahasiswa\&id $=532 \& c d=0 b 2173$

ff6ad6a6fb09c95f6d50001df6\&name=JURNAL\%20SAKINAH\%202016.pdf.

Andria Pragholapati, M.L., 2017. HUBUNGAN MASALAH KESEHATAN JIWA DENGAN STRATEGI KOPING SESEORANG YANG MENGALAMI PERCERAIAN DI KOTA BANDUNG, in: Seminar Nasional Dan Workshop Keperawatan “Penguatan Profesi Keperawatan Dalam Peningkatan Pelayanan Keperawatan" Continuum of Care Dari Ketergantungan Menuju Kemandirian Hidup Yang Berkualitas. ISBN: 978-602-14422-8-9.

Andria Pragholapati, R., 2018. DEVELOPMENT OF THE INDONESIAN NATIONAL QUALIFICATIONS FRAMEWORK FOR NURSING CURRICULUM, in: International Conference on Education and Regional Development 3rd (ICERD) 2018 “Curriculum for Generation of Discruptive and 4th Industry Revolution Era." p. 44.

Andria Pragholapati, R.M., 2017. HUBUNGAN BULLYING DENGAN KEMAMPUAN SOSIAL PADA REMAJA DI SMK MVP KOTA BANDUNG TAHUN 2017, in: Konferensi Nasional Keperawatan Kesehatan Jiwa XIV Di Kalimantan Selatan Tahun 2017.

Andria Pragholapati, T., 2018. HUBUNGAN PENGGUNAAN SMARTPHONE DENGAN KUALITAS TIDUR PADA REMAJA DI SMK X BANDUNG, in: Konferensi Nasional Keperawatan Kesehatan Jiwa XV Di Hotel Four Point By Sheraton Makassar Sulawesi Selatan. pp. 1-7.

Ardiana, F., Nurlianawati, L., Pragholapati, A., 2016. Gambaran Fungsi Kognitif Pada Lanjut Usia (Lansia) Di Panti Jompo Muhammadiyah dan Yayasan Pondok Lansia Tulus kasih.

Ariani, A., Pragholapati, A., Pratama, A.S., 2020. Information Communication Technology (ICT) In Midwifery Education: A Review of the Literature, in: The 3rd International Seminar on Global Health (ISGH) "Technology Transformation in Health Care for Better Life" Bandung, West Java, Indonesia. http://repository2.stikesayani.ac.id/index.php/isgh3/article/view/352, pp. 66-69. Ismawati, Y., Pragholapati, A., 2020. KEJADIAN GASTRITIS DI DESA CINUNUK WILAYAH KERJA PUSKESMAS CINUNUK KABUPATEN BANDUNG.

Ismawati, Y., Sumbara, Pragholapati, A., 2018. HUBUNGAN POLA MAKAN DENGAN KEJADIAN GASTRITIS DI DESA CINUNUK WILAYAH KERJA PUSKESMAS CINUNUK KABUPATEN BANDUNG.

Pragholapati, A., 2020. Self-Efficacy Of Nurses During The Pandemic Covid-19.

Pragholapati, A., 2020. COVID-19 IMPACT ON STUDENTS. osf.io.

2| P a g e 
Pragholapati, A., 2020. RESILIENSI PADA KONDISI WABAH COVID-19.

Pragholapati, A., 2020. STRES KERJA PERAWAT YANG BEKERJA DI UNIT GAWAT DARURAT (UGD) RUMAH SAKIT AL ISLAM (RSAI) BANDUNG.

Pragholapati, A., 2020. MOTIVASI KERJA PERAWAT DI RUANG RAWAT INAP RSUD MAJALAYA KABUPATEN BANDUNG.

Pragholapati, A., 2020. MENTAL HEALTH IN PANDEMIC COVID-19.

Pragholapati, A., 2020. RESILIENSI PERAWAT YANG BEKERJA DI UNIT GAWAT DARURAT (UGD) RUMAH SAKIT AL ISLAM (RSAI) BANDUNG.

Pragholapati, A., 2020. NEW NORMAL “INDONESIA” AFTER COVID-19 PANDEMIC.

Pragholapati, A., 2019. THE EFFECT OF BRAIN GYM TO THE LEVEL OF DEPRESSION IN GERIATRIC AT BALAI PERLINDUNGAN SOSIAL TRESNA WERDHA CIPARAY BANDUNG. J. Sk. Keperawatan 5, 128-146.

Pragholapati, A., Munawaroh, F., 2020. RESILIENSI PADA LANSIA. J. Surya Muda 2, 1-8.

Pragholapati, A., Ulfitri, W., 2019. Gambaran Mekanisme Coping pada Mahasiswa Program Studi Sarjana Keperawatan Tingkat IV yang Sedang Menghadapi Tugas Akhir di Sekolah Tinggi Ilmu Kesehatan X Bandung. Humanit. J. Psikol. 3, 115-126.

Prasetyo M, D., Nurlianawati, L., Pragholapati, A., 2017. GAMBARAN TINGKAT KECEMASAN PADA PASIEN PRE OPERASI FIBROADENOMA MAMMAE DI RUANG GUNTUR RUMAH SAKIT TK II DUSTIRA CIMAHI TAHUN 2017. http://ejurnal.stikesbhaktikencana.ac.id/mahasiswa.php?detail=mahasiswa\&id ....

Rahmawati, S.D., Mulyati, T., Pragholapati, A., 2015. HUBUNGAN BODY IMAGE DENGAN POLA DIET PADA REMAJA PUTRI DI SMAN 24 BANDUNG TAHUN 2015. http://ejurnal.stikesbhaktikencana.ac.id/file.php?file=preview_mahasiswa\&id ....

Rosmala, I., Jundiah, S., Pragholapati, A., 2017. TINGKAT KECEMASAN PADA KELUARGA PASIEN DI RUANG ICU RSUD MAJALAYA KABUPATEN BANDUNG TAHUN 2017.

http://ejurnal.stikesbhaktikencana.ac.id/file.php?file=preview_mahasiswa\&id=517\&cd=0b2173 ff6ad6a6fb09c95f6d50001df6\&name=Jurnal\%20Imas\%20Rosmala\%202017.pdf.

Septriani, D., Sari, Y.R., Pragholapati, A., 2019. The Relationship of Social Support With the Anxiety Level of Parents of Children with Thalassemia of Pre-School Age that Works in the Activities of Blood Transfusion in Hospital " $X$ " Bandung, in: The 2nd Bandung International Conference on Collaborative Health Research Research. Prama Grand Preanger Hotel Bandung, West Java, Indonesia 7th - 8th of October 2019. p. 12. 


\section{Editorial}

Virgona, A., Pragholapati, A., 2019. Enhancing Critical Thinking Skills in Nursing Higher Education in Preparation for the Industrial Revolution 4.0: Literature Review, in: The 3rd International Seminar on Global Health (ISGH) "Technology Transformation in Health Care for Better Life" Bandung, West Java, Indonesia.

4 | P a g e 